\title{
LUKÁCS, POLÍTICA E TRABALHO ASSOCIADO
}

\author{
LUKÁCS, POLICY AND ASSOCIATED LABOUR \\ LUKÁCS, POLÍTICA Y TRABAJO ASOCIADO
}

Rafael Rossi ${ }^{1}$

${ }^{1}$ Doutor em Educação pela UNESP. Docente do Programas de Pós-Graduação em Ensino de Ciências e do Programa de Pós-Graduação em Recursos Naturais da Universidade Federal de Mato Grosso do Sul (UFMS) - Campo Grande - MS - Brasil.

Resumo: $O$ presente ensaio serve de instrumento através do qual abordamos os fundamentos ontológicos da práxis política e da categoria do trabalho tendo, primordialmente, as contribuições do filósofo húngaro Gyorgy Lukács em sua obra Para uma Ontologia do Ser Social. Entendemos que defender a práxis política como uma atividade humana ontológica ao ser social não quer dizer necessariamente uma adesão a posicionamentos de ordem reformistas com relação à presente ordem societária regida pelo sistema do capital. O desafio está em investigar as articulações da política, sendo uma práxis ideológica, junto ao trabalho associado - como abordado por Marx - entendido como a categoria fundante de uma forma de sociabilidade superior àquela regida pelo capital. Para isso é imprescindível a compreensão tanto do trabalho quanto da política numa abordagem ontológica histórica e social.

Palavras-chave: Trabalho; Política; Trabalho Associado.

Abstract: This text serves as an instrument through which we can approach the ontological foundations of political praxis and the category of labor, based primarily on the contributions of the Hungarian philosopher Gyorgy Lukács in his work The Ontology of Social Being. We understand that to defend political praxis as an ontological human activity of the social being does not necessarily mean adhering to the positions of the reformist order in relation to the present corporate order, governed by the system of capital. The challenge lies in investigating the articulations of politics, as an ideological praxis, along with the associated labor - as expounded by Marx - understood as the founding category of a higher form of sociability than that ruled by capital. For this, it is essential to understand both work and politics in a historical and social ontological approach.

Keywords: Labor; Policy; Associated Labor.

Resumen: Este texto sirve como un instrumento a través del cual nos acercamos a los fundamentos ontológicos de la praxis política y de la categoría del trabajo, sobre todo las contribuciones del filósofo húngaro Gyorgy Lukács en su libro Ontología del Ser Social. Entendemos que la defensa de la praxis política como una actividad humana ontológica del ser social no significa necesariamente una adhesión a posiciones de orden reformista con respecto a este orden social que se rige por el sistema de capital. El reto es investigar las articulaciones de la política como una práctica ideológica, con el trabajo asociado - como es comentado por Marx - entendido como la categoría básica de una forma más elevada de la sociabilidad en relación a la que rige el capital. Para ello es imprescindible la comprensión tanto del trabajo como de la política en un enfoque ontológico histórico y social.

Palabras clave: Trabajo; Política; Trabajo Asociado. 
Tratar de um tema como o da política já é uma polêmica em qualquer ocasião. Todavia, não tratamos desta temática em um momento histórico qualquer. Ao contrário, assim o procedemos em meio à crise estrutural do capital (MÉSZÁROS, 2002), perante um grave período de derrotas do movimento operário e de avalanche da perspectiva reformista sobre os mais diversos contextos das lutas sociais. Esta crise não é apenas mais uma crise periódica ou cíclica que "sempre" enfrentávamos. A crise estrutural do capital afeta todas as dimensões e esferas da vida social, desde nossas escolas, universidades, sindicatos, movimentos sociais, igrejas e partidos políticos até nossa casa, família e a relação de nós mesmos com os outros. A manifestação desta crise estrutural ocorre de modo diferenciado, já que alguns territórios sofrem mais fortemente as influências e as desigualdades do agronegócio, por exemplo, enquanto que outros sentirão de modo mais acentuado as múltiplas situações de violência. Todavia, apesar do caráter de manifestação territorial desigual desta crise estrutural, todos estes impactos estão dentro da lógica de reprodução do próprio capital. Por isso, não há espaço que fique ileso, não há sequer um complexo social que não seja impactado pelo capital em sua crise mais íntima, profunda e extensa dos últimos tempos.

Isso nos coloca um desafio extra, por assim dizer. Se na época de Marx suas ideias e análises já estavam sendo deturpadas e "revisadas", hoje, para muitos (intelectuais ou não), a obra marxiana não passa de quinquilharia de museu. Não por um acaso, uma série de processos complexos e intrincados entre si fizeram com que o movimento operário, cada vez mais, desse "adeus" à discussão sobre a categoria trabalho e, com isso, passassem a supervalorizar a política como dimensão resolutiva por excelência das lutas sociais. Interessante análise, neste sentido - e que comungamos do posicionamento dos autores -, é desenvolvida por Tonet e Nascimento (2009) que, inclusive, defendem enfaticamente a centralidade do trabalho como o "eixo da luta revolucionária" e não a política.

Dessa forma, no presente texto - que não tem mais do que a pretensão de ser um ensaio -, analisamos a práxis política a partir das contribuições presentes na obra Para uma Ontologia do Ser Social de Gyorgy Lukács. Compreendemos que é importante recorrermos à análise "genética" sobre a origem ontológica de cada complexo social que estivermos analisando para entendê-los em suas distintas funções na reprodução social. Para isso, é preciso partir da atividade sensível primária do "mundo dos homens" que é o trabalho e compreender a relação que se estabelece entre esta atividade sensível primária e a totalidade social. Deste modo, não há nenhum reducionismo, mecanicismo ou economicismo na ontologia marxiana, mas sim a compreensão da realidade objetiva se conformando numa totalidade rica e plena de determinações. É preciso compreender, em primeiro lugar, a relação de dependência ontológica dos complexos para com o trabalho, a autonomia relativa, determinação recíproca que o trabalho e a totalidade exercem.

O grande problema que nos instiga na elaboração deste texto é: a política é inerente ao ser social (assim como o são o trabalho, a educação, a arte, etc.) ou se trata de algo exclusivo 
apenas às sociedades de classe e, nesse caso, numa sociedade comunista (ou seja, de trabalho emancipado) não haverá espaço para a política? Temos clareza que esta problemática não será resolvida de modo tão rápido e simples. Trata-se de um tema por demais complexo e que precisa ser analisado com calma. Todavia, entendemos que as contribuições de Lukács em sua "Ontologia" possuem indícios de suma importância no tratamento desta questão. Isso se dá não por uma simplória escolha acadêmica, mas sim porque nesta obra se encontram formulações que emanam da própria lógica do processo histórico real.

É preciso analisar a práxis política a partir de sua origem histórico-ontológica e desenvolvimento no processo de complexificação do ser social. Para responder esta indagação com um mínimo de profundidade na análise é necessário, desta forma, uma abordagem de ordem ontológica marxiana, que se preocupe em apreender idealmente as categorias imanentes da própria realidade objetiva, num processo que, cada vez mais, "encharca" de determinações o objeto em questão. É preciso, portanto, buscar a origem, a natureza e a gênese da política tendo como parâmetro o conjunto do processo histórico e real.

Com efeito, na primeira parte do texto, iremos retomar - brevemente - uma análise sobre a centralidade ontológica do trabalho e as articulações que se estabelecem no âmbito da reprodução social, pois como o próprio Lukács afirma: "para expor em termos ontológicos as categorias específicas do ser social, seu desenvolvimento [...] é preciso começar essa tentativa com a análise do trabalho" e isso, por sua vez, sem se esquecer de que as categorias "só podem ser compreendidas adequadamente no interior e a partir da constituição global do nível de ser de que se trata" (LUKÁCS, 2013, p. 41). Ou seja: não se trata de reduzir o ser social, mecanicamente, ao trabalho, mas compreender a gênese ontológica dos complexos sociais em sua articulação com o trabalho como categoria que funda o ser social.

Na segunda parte, analisaremos a práxis política inserida na discussão de ideologia, tal como analisado por Lukács em sua "Ontologia do Ser Social". Tal procedimento é preciso, pois para compreender a natureza de uma "entidade ideológica" é preciso que se articule "a análise imanente dos textos que a explicitam com a investigação de sua gênese histórica e com a da função social que desempenha" (CHASIN, 1978, p. 78). Já na terceira parte explicitaremos os vínculos entre a práxis política e a "centralidade ontológica do trabalho na transição do capitalismo rumo ao socialismo" (TONET, 2014), com intuito de compreender o correto equacionamento entre elas. Por fim, nossas considerações finais retomam alguns pontos fundamentais a respeito deste importante e polêmico debate.

\section{TRABALHO: MODELO DA PRÁXIS SOCIAL}

Os homens não se tornam seres humanos apenas e tão somente por aspectos meramente biológicos. Certamente, sem a reprodução biológica não há reprodução social. Todavia, esta última envolve uma série de complexos eminentemente sociais e, ainda - para utilizar uma expressão de Lukács -, engloba um "afastamento das barreiras naturais". Como isso é possível no ser social? A partir da atividade básica e presente em todas as formações sociais: o trabalho. 
A produção de valores de uso ou bens não muda sua natureza geral por se realizar para o capitalista e sob seu controle. Por isso, o processo de trabalho deve ser considerado de início independentemente de qualquer forma social determinada. Antes de tudo, o trabalho é um processo entre o homem e a Natureza, um processo em que o homem, por sua própria ação, media, regula e controla seu metabolismo com a Natureza. Ele mesmo se defronta com a matéria natural como uma força natural. Ele põe em movimento as forças naturais pertencentes a sua corporalidade, braços e pernas, cabeça e mão, a fim de apropriar-se da matéria natural numa forma útil para sua própria vida. Ao atuar, por meio desse movimento, sobre a Natureza externa a ele e ao modificá-la, ele modifica, ao mesmo tempo, sua própria natureza. Ele desenvolve as potências nela adormecidas e sujeita o jogo de suas forças a seu próprio domínio. Não se trata aqui das primeiras formas instintivas, animais, de trabalho. (MARX, 1996, p.297, grifos nossos).

Este trecho de "O Capital" é bem elucidativo e esclarecedor. Vemos que Marx, inicialmente, chama a atenção para a concepção ampla de trabalho - ontológica - presente "independentemente de qualquer forma social determinada" e, neste sentido, o trabalho é sempre "um processo entre o homem e a natureza". O homem movimenta a natureza; a modifica com sua "corporalidade, braços e pernas, cabeça e mão", com intuito de "apropriar-se da matéria natural numa forma útil para sua própria vida". Portanto, em um sentido ontológico, o trabalho envolve o metabolismo homem (sociedade) e a natureza com a função social (ou seja, a função que exerce no processo de reprodução social) de transformação da natureza para a produção de valores de uso, de "forma útil para sua própria vida". Ao trabalhar o homem, também, "modifica, ao mesmo tempo, a sua própria natureza", pois desenvolve uma série de conhecimentos, habilidades, técnicas, etc., que poderá Ihe ser útil em uma série de outras atividades que não propriamente o trabalho e, com isso, outros complexos sociais irão se originar e se desenvolver. Por isso, o trabalho é a única categoria que funda o ser social e todos os demais complexos são por ele fundados. Esta é - em linhas gerais - a centralidade ontológica do trabalho.

Uma aranha executa operações semelhantes às do tecelão, e a abelha envergonha mais de um arquiteto humano com a construção dos favos de suas colmeias. Mas o que distingue, de antemão, o pior arquiteto da melhor abelha é que ele construiu o favo em sua cabeça, antes de construí-lo em cera. No fim do processo de trabalho obtém-se um resultado que já no início deste existiu na imaginação do trabalhador, e portanto idealmente. Ele não apenas efetua uma transformação da forma da matéria natural; realiza, ao mesmo tempo, na matéria natural seu objetivo, que ele sabe que determina, como lei, a espécie e o modo de sua atividade e $\backslash$ ao qual tem de subordinar sua vontade. E essa subordinação não é um ato isolado. Além do esforço dos órgãos que trabalham, é exigida a vontade orientada a um fim, que se manifesta como atenção durante todo o tempo de trabalho, e isso tanto mais quanto menos esse trabalho, pelo próprio conteúdo e pela espécie e modo de sua execução, atrai o trabalhador, portanto, quanto menos ele o aproveita, como jogo de suas próprias forças físicas e espirituais. (MARX, 1996, p.298, grifos nossos).

Outro ponto fundamental é a questão da "vontade orientada a um fim". Para efetivar os atos de trabalho, os homens precisam se apropriar de um conhecimento - mesmo que imperfeito e nunca absoluto - a respeito da realidade objetiva para que o fim pretendido seja alcançado. Nessa perspectiva, o campo de escolhas e de possibilidades com que os homens se defrontam parte da própria realidade objetiva. Temos, desse modo, a prioridade ontológica da objetividade sobre a subjetividade. Não importa querer fazer uma lança de madeira para pescar se o local em que estou não há qualquer tipo de madeira, por exemplo. Vemos, portanto, que por meio da análise do trabalho temos a correta correlação entre subjetividade e 
objetividade. É de extrema importância a construção idealmente de um projeto de trabalho, todavia este projeto que fora elaborado primeiro "na cabeça" e depois objetivado só fora possível a partir da própria realidade objetiva. É justamente por isso que Marx afirma que: "O modo de produção da vida material condiciona o processo de vida social, política e intelectual. Não é a consciência dos homens que determina o seu ser; ao contrário, é o seu ser social que determina sua consciência" (MARX, 2008, p. 47, grifos nossos). O que envolve, pois, o trabalho?
Os elementos simples do processo de trabalho são a atividade orientada a um fim ou o trabalho mesmo, seu objeto e seus meios [...] Todas as coisas que o trabalho só desprende de sua conexão direta com o conjunto da terra, são objetos de trabalho preexistentes por natureza. Assim o peixe que se pesca ao separá-lo de seu elemento de vida, a água, a madeira que se abate na floresta virgem, o minério que é arrancado de seu filão. Se, ao contrário, o próprio objeto de trabalho já é, por assim dizer, filtrado por meio de trabalho anterior, denominamo-lo matéria-prima. Por exemplo, o minério já arrancado que agora vai ser lavado. Toda matéria-prima é objeto de trabalho, mas nem todo objeto de trabalho é matéria-prima. O objeto de trabalho apenas é matéria-prima depois de já ter experi- mentado uma modificação mediada por trabalho. $O$ meio de trabalho é uma coisa ou um complexo de coisas que o trabalhador coloca entre si mesmo e o objeto de trabalho e que the serve como con- dutor de sua atividade sobre esse objeto. Ele utiliza as propriedades mecânicas, físicas, químicas das coisas para fazê-las atuar como meios de poder sobre outras coisas, conforme o seu objetivo. (MARX, 1996, p.298).

Se o trabalho envolve o metabolismo homem e natureza, ele deve envolver, sempre (e independente de qual formação social estivermos analisando: escravismo, feudalismo, capitalismo ou comunismo) uma "atividade orientada a um fim, seu objeto e seus meios". Esta constatação é de fundamental importância, para não incorrermos no equívoco de considerarmos o conhecimento, por exemplo, como um "instrumento de trabalho". Como já afirmamos, o conhecimento é imprescindível para que o fim pretendido possa ser alcançado, porém, Marx é claro que nos atos de trabalho a matéria-prima é um objeto "filtrado por meio de trabalho anterior", ou seja, só é matéria-prima se tiver "experimentado uma modificação mediada por trabalho". O meio de trabalho é, sempre, "uma coisa ou um complexo de coisas que o trabalhador coloca entre si mesmo e o objeto de trabalho" e, portanto, é impossível considerarmos o conhecimento ou a educação como objetos ou meios de trabalho.

Em suma, o trabalho, como diria Lukács, possibilitou o "salto ontológico" (salto qualitativo/ essencial) que "retira a existência humana das determinações meramente biológicas" e, em razão disto, "não pode haver existência social sem trabalho" (LESSA, 2012, p. 25). Entretanto, é preciso destacar que a realidade social não pode ser resumida apenas ao trabalho. Começar a investigação a partir desta categoria fundante é fundamental, pois a partir dela que os outros complexos sociais "são chamados à vida" (LUKÁCS 1978). Todavia, é preciso considerar que:

Para expor em termos ontológicos as categorias específicas do ser social, o seu surgimento a partir das formas de ser precedentes, de que maneira as categorias se vinculam a essas formas, como aquelas se fundamentam nestas e se diferenciam destas, é preciso começar pela análise do trabalho. É claro que não se deve esquecer que cada grau do ser, no seu conjunto e nos seus detalhes, constitui um complexo, isto é, que também suas categorias mais centrais e determinantes só podem ser concebidas no interior e a partir da estrutura global do nível de ser de que se trata. Um olhar muito superficial ao ser social mostra a inextricável imbricação em que se encontram suas categorias decisivas como o trabalho, a linguagem, a cooperação e a divisão do trabalho; monstra que aí surgem novas relações da consciência com a realidade e, portanto, consigo mesma etc. Nenhuma categoria pode ser adequadamente compreendida se for considerada isoladamente [...] (LUKÁCS, 1981, p. 01) 
Este trecho de Lukács (1981) é relevante em ser ponderado, pois mostra que o trabalho se constitui na única categoria que funda o ser social e isso, por sua vez, justamente, por ser nesta práxis que aparece pela primeira vez um pôr teleológico. Isto quer dizer que, sempre de acordo com Lukács (1981), no trabalho o ser humano consegue, por meio da sua consciência, perceber as possibilidades de articulações existentes nos elementos da realidade natural e, por meio de sua ação prática, desencadear um processo de objetivação que, por fim, instaura algo que não existia antes na natureza. O exemplo que o filósofo húngaro utiliza é o de uma casa:

Tudo isto é mostrado muito plasticamente pelo exemplo da construção de uma casa, utilizado por Aristóteles. A casa tem um ser material tanto quanto a pedra, a madeira, etc.; no entanto, a posição teleológica faz surgir uma objetividade inteiramente diferente com relação aos elementos primitivos. Nenhum desenvolvimento imanente das propriedades, das legalidades e das forças operantes no mero ser-em-si da pedra ou da madeira pode fazer "derivar" uma casa. Para que isto aconteça é necessário o poder do pensamento e da vontade humana, que organize material e fundamentalmente tais propriedades de uma forma inteiramente nova. (LUKÁCS, 1981, p. 14).

Nesse aspecto a consciência humana desempenha um papel extremamente ativo, no âmbito de um pôr teleológico, todavia (e isto é importantíssimo para não cairmos no idealismo) é sempre a realidade objetiva que coloca o campo de possibilidades reais e concretas sobre as quais a consciência tem de refletir, interpretar, captar, compreender e atuar.

Com efeito, o trabalho, se configurando como um pôr teleológico primário (homemnatureza), envolve sempre uma teleologia, objetivação, exteriorização e causalidade posta. A teleologia articula a prévia-ideação à objetivação, ou seja, à criação material daquilo que antes apenas existia idealmente. Portanto, a "objetivação é, segundo Lukács, o momento do trabalho pelo qual a teleologia se transmuta em causalidade posta" (LESSA, 2012, p. 64). Causalidade posta quer dizer uma lógica "colocada" pela ação histórica e social dos homens por meio dos atos do trabalho e, com efeito, é qualitativamente da causalidade dada pelo próprio movimento da natureza. Uma lança para pescar, por exemplo, continua sendo um pedaço de madeira, todavia, também é um instrumento social que se generalizou e que, agora, possui uma história independente de quem a criou. Lukács afirma, em razão disto, que: "os atos do trabalho apontam necessária e ininterruptamente para além de si mesmos" (LUKÁCS, 2013, p. 118). Para entender melhor a relação entre teleologia e causalidade, é preciso refletir sobre a explicação lukácsiana:

Com efeito, a busca dos meios para realizar o fim não pode deixar de implicar um conhecimento objetivo acerca da criação daquelas objetividades e dos processos cujo pôr em movimento pode levar a alcançar o fim posto. A posição do fim e a busca dos meios nada podem produzir de novo na medida em que a realidade natural, enquanto tal, deve permanecer sendo o que é em si mesma: um sistema de complexos cuja legalidade continua a operar com total indiferença ante a todas as aspirações e esforços do homem. Aqui a busca tem uma dupla função: de um lado evidencia aquilo que se faz presente em si nos objetos em questão, independentemente de toda consciência; de outro lado, descobre neles aquelas novas conexões, novas possíveis funções que, quando postas em movimento, tornam efetivável o fim teleologicamente posto. No ser-em-si da pedra não há nenhuma intenção, e até nem sequer um indício da possibilidade de ser usada como faca ou como machado; mas só pode adquirir uma tal função de instrumento quando suas propriedades objetivamente presentes, existentes em si sejam adequadas para entrar numa combinação tal que torne isto possível. E isto, no plano ontológico, pode ser encontrado claramente já no estágio mais primitivo. Quando o homem primitivo escolhe uma pedra para usá-la, por exemplo, como machado, deve reconhecer corretamente este nexo entre as propriedades da pedra - que nas mais das vezes tiveram uma 
origem causal - e a possibilidade do seu uso concreto. Somente assim ele efetua aquele ato de consciência analisado por Aristóteles e Hartmann; e quanto mais o trabalho se desenvolve, tanto mais evidente se torna esta situação. (LUKÁCS, 1981, p. 15-16).

Lukács nos explica que, para que, de fato, um pôr teleológico possa se originar, é fundamental que a consciência realize a busca dos meios, isto é, que ela procure os possíveis nexos, articulações e vínculos que podem ser realizados entre os elementos da realidade objetiva para atingir o fim previamente idealizado. Isto quer dizer que, no pôr teleológico, há o papel ativo da consciência e a instauração de um processo de objetivação que insere algo que antes não existia na natureza. Como o filósofo argumenta, pedra e madeira existem na natureza, mas uma casa não. A objetivação cria algo fruto da ação social, da ação dos seres humanos sobre um pedaço ou parte da natureza para atingir um determinado fim. Com isso, o rol de possibilidades para intervir na realidade se torna muito maior, após os atos de trabalho, do que aquele que existia antes da atividade laborativa. Por isso mesmo, o trabalho é a única categoria fundante do ser social e nele "estão contidas in nuce todas as determinações" que "constituem a essência do novo ser social" (LUKÁCS, 2013, p. 35).

A partir das reflexões elaboradas até o momento, entendemos que é fundamental considerar as relações que se estabelecem entre os distintos complexos sociais que surgem a partir dos atos de trabalho e a relação que eles mantêm para com essa práxis ontológica primária. Nesse aspecto, Tonet (2005), a partir dos escritos da Ontologia de Lukács, formula que as relações que as dimensões sociais possuem para com o trabalho são: 1) dependência ontológica dos complexos sociais para com o trabalho (educação, arte, filosofia e ciência, por exemplo, são complexos fundados e não fundantes!); 2) autonomia relativa dos complexos frente ao trabalho (cada um possui uma função social específica diferente da do trabalho); e 3) determinação recíproca que se estabelece entre eles (TONET, 2005; LUKÁCS, 2012). Como estas articulações apresentam uma importância enorme, vale a pena nos debruçar sobre essa questão um pouco mais.

A dependência ontológica indica que educação, arte, filosofia, ciência, etc., apenas podem surgir no ser social, porque os homens são capazes de trabalhar. Caso cancelemos o trabalho, cancelaremos também a reprodução social. Cada um desses complexos possui uma autonomia relativa frente ao trabalho. Isso ocorre, pois, a educação, por exemplo, possui como função social a transmissão e a apropriação dos conhecimentos acumulados pela humanidade. Todavia, o trabalho assalariado (forma concreta do trabalho no capitalismo) faz como que apenas alguns conhecimentos sejam transmitidos e, sempre, numa determinada concepção de mundo. Já a determinação recíproca implica entender que cada um dos complexos sociais interfere no trabalho e por ele também sofre interferência. A totalidade, nesta linha de raciocínio, exerce o "momento predominante" na orientação de cada complexo. Pensemos no caso da ciência no capitalismo. Em vários sentidos a ciência progrediu e desenvolveu enormes avanços, entretanto, tais progressos não são - no seu conjunto - para atender e satisfazer as necessidades humanas, mas sim as necessidades do capital. Temos inúmeras pesquisas que comprovam que agrotóxicos e transgênicos causam câncer, porém cada vez mais consumimos alimentos com estas substâncias. Não falta conhecimento científico e/ou tecnológico. É uma 
questão de como os homens organizam, no capitalismo, as relações entre si no processo de transformação da natureza.

Com estas reflexões, fica impossível imputar um aspecto reducionista à ontologia marxiana, pois o ser social pode, então, ser compreendido como um "complexo de complexos" (LUKÁCS, 2013) e a práxis política pode ser entendida em sua universalidade.

\section{IDEOLOGIA E POLÍTICA}

Uma vez que compreendemos, em linhas rápidas, a centralidade ontológica do trabalho e as relações que ele consubstancia no ser social, podemos, agora, avançar para o entendimento da práxis política. Nossa exposição, deste modo, contará com as contribuições que Lukács em sua "Ontologia do Ser Social" nos oferece a esse respeito e, também, com as elaborações de autores que seguiram as "pistas" deixadas pelo filósofo húngaro.

Em primeiro lugar é fundamental diferenciar as "posições teleológicas". As posições teleológicas primárias - o trabalho - realizam a interação entre sociedade e natureza; já as posições teleológicas secundárias se consubstanciarão na "tentativa de induzir outra pessoa (ou grupo de pessoas) a realizar, por sua parte, pores teleológicos concretos" e, por isso, "esta segunda forma de pôr teleológico, no qual o fim posto é imediatamente um pôr do fim por outros homens, já pode existir em estágios muito iniciais" (LUKÁCS, 2013, p. 63). Como afirmamos na primeira parte do texto, no trabalho, surge pela primeira vez um pôr teleológico, todavia, mesmo em seus inícios mais rudimentares, também se originam pores teleológicos que não possuem mais como finalidade a transformação da natureza, mas sim induzir outros seres humanos a efetivarem outras práxis.

Esta posição teleológica secundária, de acordo com Lukács (1981), por lidar com os próprios seres humanos e não mais com a realidade natural de modo imediato, possui um grau de imprevisibilidade muito maior do que o trabalho como uma posição teleológica primária. Algo em comum nas duas posições teleológicas é o fato de que "em todas se dá uma tomada de decisões entre alternativas" e as diferenças se dão no sentido de que "os objetos das posições teleológicas secundárias são os próprios homens" e, também, há que se considerar o "grau de incerteza que permeia essas posições" (VAISMAN, 1996, p. 106).

Estes entendimentos são necessários, pois um dos lugares da "Ontologia" luckasiana em que é tratada a práxis política se dá no capítulo da ideologia. Contrariando uma enorme corrente teórica interpretativa a respeito do fenômeno ideológico, Lukács não parte de um ponto de vista gnosiológico, mas sim ontológico, isto é, a história real e concreta é o solo privilegiado de análise, tendo por base a própria lógica de complexificação do ser social. É o que percebemos, por exemplo, quando o autor afirma que: "enquanto alguma ideia permanecer o produto do pensamento ou a alienação do pensamento de um indivíduo, por mais que seja dotada de valor ou de desvalor, ela não pode ser considerada como ideologia" (LUKÁCS, 2013, p. 335). O critério "clássico", por assim dizer, de falso ou verdadeiro, fica restrito ao ponto de vista gnosiológico no exame da ideologia. Já para o ponto de vista ontológico marxiano: 
A ideologia é sobretudo a forma de elaboração ideal da realidade que serve para tornar a práxis social humana consciente e capaz de agir. Desse modo, surgem a necessidade e a universalidade de concepções para dar conta dos conflitos do ser social; nesse sentido, toda ideologia possui o seu serpropriamente-assim social: ela tem sua origem imediata e necessariamente no hic et nunc social dos homens que agem socialmente em sociedade. (LUKÁCS, 2013, p. 335, grifos nossos),

Em suma, podemos compreender a ideologia como "o momento ideal que antecede o desencadeamento da ação, nas posições teleológicas secundárias" (VAISMAN, 1996, p. 107). Essa interpretação é possível, pois:
Na medida em que o ser social exerce determinação sobre todas as manifestações e expressões humanas, qualquer reação, ou seja, qualquer resposta - que os homens formulem em relação aos problemas postos pelo seu ambiente econômico-social - pode, ao orientar a prática social, ao conscientizar e oferecer respostas, tornar-se ideologia. Ou seja, ser ideologia não é um atributo específico desta ou daquela expressão humana, mas, qualquer uma destas, dependendo das circunstâncias, pode se tornar ideologia. (VAISMAN, 1996, p. 109, grifos nossos).

A política e a ideologia, por seu turno, se encontram no âmbito das posições teleológicas secundárias. Podemos perceber dois sentidos de ideologia em Lukács. Um sentido amplo, indicando que "ideologia e existência social (em qualquer nível de desenvolvimento) são inseparáveis" e, com isso, "onde se manifeste o ser social há problemas a resolver e respostas que visam sua solução; é precisamente nesse processo que o fenômeno ideológico é gerado e tem seu campo de operações" (VAISMAN, 1996, p. 110). E, por conseguinte, também existe a concepção restrita que envolve a presença de conflitos sociais e, neste caso, a "ideologia se volta à resolução dos problemas agora transpassados por este conflito básico", o que quer dizer que "a ideologia passa a se manifestar como um instrumento ideal através do qual os homens e as classes se engajam nas lutas sociais, em diversos planos e níveis" (VAISMAN, 1996, p. 110). Em síntese:

[...] na tematização luckásiana, o fenômeno da ideologia é analisado sob fundamento onto-prático, e não sob critério científico-gnosiológico, pois, a utilização deste último conduz irremediavelmente a erro na avaliação do fenômeno. Falar de ideologia em termos onto-práticos significa, portanto, analisar este fenômeno essencialmente pela função social que desempenha, ou seja, enquanto veículo de conscientização e prévia ideação da prática social dos homens. (VAISMAN, 1996, p. 112, grifos nossos),

Tais elucidações são de fundamental relevância para a apreensão da práxis política no pensamento do filósofo húngaro. Não estamos trazendo as contribuições luckasianas e de seus intérpretes por pura preferência intelectual/acadêmica, como já assinalamos, mas sim por reconhecer nas análises deste autor (e também nas de Marx) critérios da problemática aqui tratada numa perspectiva onto-prática, tendo por base a realidade objetiva em seu processo de complexificação a partir da atividade ontológica-primária dos homens. A ideologia é, deste modo, ontológica ao ser social. Lukács chega a citar como exemplo a astronomia heliocêntrica ou a teoria do desenvolvimento no âmbito da vida orgânica. Ambas são teorias científicas, porém só "depois da atuação de Galileu ou Darwin, os posicionamentos relativos às suas concepções se converteram em meios para travar os combates em torno dos antagonismos sociais" e, com efeito, "elas se tornaram operantes - nesse contexto - como ideologias" (LUKÁCS, 2013, p. 337).

Para o pensador húngaro, a política é uma forma específica de ideologia. Já a arte e a filosofia, por sua vez, são ideologias puras. A ideologia é mais ampla que a política, já que 
engloba a religião, a arte, o direito, etc. (HOLANDA, 2014). As formas específicas "são aquelas manifestações diretamente voltadas para a ação direta sobre a economia e sobre as estruturas sociais a ela relacionadas" e as formas puras de ideologia têm o seu "desdobramento" atuando "na prática por meio da ação política ou até mesmo do direito" (VAISMAN; FORTES, 2014, p. 122). Neste sentido, a política é uma forma específica de ideologia que corresponde "àqueles conjuntos de atividades e elaborações ideais por meio das quais os homens tomam consciência e enfrentam os conflitos de toda a sociedade" e, por conseguinte, a práxis política "é um pôr teleológico que modifica o mundo fenomênico" movimentando "alternativas postas pela essência dos processos sociais, com o claro intuito de transformar a essência" (VAISMAN; FORTES, 2014, p. 123).

A política visa atingir à totalidade social, todavia ela apenas pode agir sobre as "diretrizes tendenciais caracterizadas dessa totalidade, atuando no plano da imediaticidade" (VAISMAN; FORTES, 2014, p. 124). Com efeito, é preciso compreender a política num sentido amplo e, depois, analisarmos cada caso concreto na influência que ela sofre com a entrada em cena da propriedade privada, do direito, do Estado, das classes sociais e da exploração do homem pelo homem. Como bem esclarece Carli (2013), não se pode confundir o Estado com a política, pois "diferentemente da segunda, o primeiro encontra-se apenas em sociedades cindidas em classes" (CARLI, 2013, p. 39). Assim:
A política, no entanto, consegue disponibilizar ao homem a consciência de pertencimento a seu gên- ero ao mesmo tempo em que se vincula de modo mais imediato à práxis cotidiana. Quando uma tribo interrompe suas tarefas cotidianas (caça, coleta, pesca etc.) para discutir o que fazer diante de uma guerra iminente, os seus membros assim se comportam politicamente ao debater o destino de sua generalidade concreta, ainda que seja diante de um fenômeno imediato como a referida guerra. A arte nos concede esta generalidade sem se vincular ao imediato de forma tão estreita. As conexões que um manifesto partidário traça com as lutas cotidianas são mais nítidas do que aquelas que estão contidas nos dramas de Ibsen, nas sinfonias de Beethoven, nas catedrais bizantinas, numa epopeia de Homero, nas pinturas rupestres ou em qualquer outra obra de produção artística. (CARLI, 2013, p. 30, grifos nossos).

Observamos, claramente, que não há porque confundirmos política com o Estado. A práxis política é inerente a toda forma de sociabilidade humana, como exemplificado por Carli (2013). Poderíamos elencar vários outros exemplos: quando uma tribo na sociedade primitiva decidia que as crianças com algum tipo de deficiência tinham de ser abandonadas na selva se tratava de uma decisão política e que, portanto, afetava a totalidade daquela sociedade. Precisamos, dessa forma, compreender a política em um sentido amplo/ontológico e, ao mesmo tempo, as influências qualitativas que sofrem com o aparecimento das sociedades de classes. Com o capitalismo, por exemplo, a "política assume como uma de suas dimensões aquela descrita por Marx e Engels no Manifesto comunista", ou seja, "torna-se igualmente a organização do poder de um grupo de indivíduos sobre o outro" e isso se refere a uma "transformação qualitativa porque responde a novas circunstâncias históricas" (CARLI, 2013, p. 41). É esta distinção que permite Lukács afirmar que:

Não pode haver nenhuma comunidade humana, por menor que seja, por incipiente que seja, na qual e em torno da qual não aflorassem ininterruptamente questões que, num nível desenvolvido, habituamo-nos a chamar de políticas. É impossível dar uma definição, isto é, fixar em termos de pensamento formal os limites, onde começa ou então termina a política. (LUKÁCS, 2013, p. 361, grifos nossos). 
E continua:

A política é um complexo universal da totalidade social, só que se trata de um complexo da práxis, mais precisamente, da práxis mediada, que, por isso mesmo, de modo algum tem a possibilidade de ter uma universalidade tão identicamente espontânea e permanente como a linguagem enquanto órgão primordial da apropriação do mundo através da objetivação dos objetos, bem como dos sujeitos que os põem pela alienação e se apropriam deles [...] A política é uma práxis que, em última análise, está direcionada para a totalidade da sociedade, contudo, de tal maneira que ela põe em marcha de modo imediato o mundo fenomênico social como terreno do ato de mudar, isto é, de conservar ou destruir o existente em cada caso; contudo, a práxis desencadeada desse modo inevitavelmente é acionada de modo mediado também pela essência e visa, de modo igualmente mediado, também à essência. (LUKÁCS, 2013, p.362, grifos nossos).

Nestas citações há elementos importantíssimos para nosso debate. Em primeiro lugar, é preciso enfatizar que não é possível "haver nenhuma comunidade humana, por menor que seja" na qual não surgissem, ou seja, "aflorassem ininterruptamente" questões políticas. Este é o caráter ontológico desta práxis como descrito no exemplo de Carli (2013), baseado na análise de Lukács. A práxis política se dirige, como afirmamos, à "totalidade da sociedade" e esta práxis é acionada de "modo mediado" pela essência visando, de modo "igualmente mediado", também à essência.

Para analisarmos - ontologicamente - cada complexo e práxis, devemos procurar entender a sua origem histórica e, também, a posição/função ocupada por este complexo ou práxis no processo de reprodução social. Se assim o procedermos com a práxis política, veremos que sua função social é colocar em "marcha de modo imediato o mundo fenomênico social como terreno do ato de mudar" e, com isso, também é acionada "de modo mediado" pela essência (LUKÁCS, 2013, p. 362). Aqui reside a importância em não confundirmos política com Estado.

A política não deve ser confundida com poder político ou política estatal. Estes últimos só aparecerem na história da humanidade uma vez que a propriedade privada - entendida como a ação de uma classe se apropriar privadamente do fruto do trabalho de outra classe entrou em cena. A práxis política, por seu turno, é ontológica ao ser social, pois diz respeito à práxis ideológica que tem por finalidade atingir as estruturas econômicas de uma determinada formação social, ou seja, os rumos de uma totalidade. Isto não desqualifica ou menospreza o trabalho como categoria fundante do ser social e a sua relevância social - rumo ao trabalho associado - no processo de superação do capital.

Numa concepção mais estrita, um critério de análise para a "práxis ideológico-política" diz respeito aos conflitos reais, "de causas em última instância econômicas" e como estes conflitos podem ser enfrentados e "resolvidos com meios políticos". Consequentemente, em decorrência deste critério imediato, temos que analisar a duração de uma solução desse aspecto. Todavia, quando nos remetemos ao caráter da duração não se trata efetivamente de "nenhum lapso de tempo abstrato" ou "quantitativamente determinável", mas sim no sentido de perceber se "os novos momentos causais postos em marcha no pôr teleológico, não importando com que grau de consciência isso seja feito, influem efetivamente nas tendências econômicas decisivas que entraram em crise" (LUKÁCS, 2013, p. 365). Portanto:

[...] a duração pode proporcionar um critério para uma decisão política somente na medida em que suas consequências atestarem claramente que ela, não importando com que fundamentação ideológ- 
ica, foi capaz de incidir em certas tendências reais do desenvolvimento social, se e como as cadeias causais desencadeadas por ela influíram efetivamente nesse desenvolvimento. (LUKÁCS, 2013, p. 365, grifos nossos).

Aqui cabe uma relevante consideração a respeito da articulação entre trabalho, ideologia e política em sentido estrito. Vimos como que todos os complexos possuem uma dependência ontológica para com o trabalho, isto é: não é possível existir ideologia, política e nem reprodução social sem a efetivação dos atos do trabalho. Contudo, quando analisamos o modo de produção capitalista sendo uma formação social historicamente construída, também temos de levar em consideração a determinação que o trabalho assalariado/abstrato e a totalidade social impõem à ideologia e à política. Se a atividade vital humana, no capitalismo, se transforma em trabalho assalariado/abstrato, certamente este fato também irá interferir e influenciar o complexo da ideologia e a práxis política. A ideologia dominante, como Marx e Engels já haviam sinalizado, será a ideologia das classes dominantes e a política será em seu conjunto - para a manutenção do sistema do capital. Nossa intenção é explicitar o caráter amplo e estrito da política no ser social. Entretanto, também temos a necessidade de reafirmar a defesa da centralidade ontológica do trabalho na transição do capitalismo rumo ao socialismo, como abordamos no item a seguir.

\section{Política e tRabalHo ASSOCIADO}

No primeiro item deste artigo tratamos da centralidade ontológica do trabalho e as relações que se consubstanciam na reprodução social. A ontologia marxiana permite compreender que o trabalho - em seu sentido ontológico - não se resume e nem se esgota no trabalho assalariado/abstrato que funda a totalidade social no modo de produção capitalista. Este último é a forma histórica do trabalho no capitalismo. A função social de transformar a natureza para produzir os valores de uso contínuo, todavia, se trata, agora, de produzir da maneira necessária para atender os interesses de reprodução do capital.

O mesmo ocorre com a práxis política. Já percebemos anteriormente que a práxis política é ontológica ao ser social e que ela não deve ser confundida com a política estatal. A função social que a política exerce é afetar o fenomênico, mediando a essência e atuando sobre as estruturas sociais produtivas. Todavia, com o surgimento da propriedade privada e do trabalho alienado, podemos afirmar que a política, assim como os demais complexos sociais, fora privatizada, ou seja, ela irá atender - predominantemente - os interesses particulares das classes dominantes.

Agora, temos que esclarecer ainda mais um ponto importante do debate: se tanto o trabalho quanto a política - em sentido ontológico - se distinguem de suas formas típicas no modo de produção capitalista (trabalho assalariado e política burguesa), sem contudo desaparecerem; de que modo eles se articulam na necessidade histórica de superação do capital e de construção do socialismo?

Neste aspecto, vale a pena considerarmos uma indagação: quais trabalhadores, dentre os assalariados, produzem no capitalismo o "conteúdo material da riqueza social"? Se voltarmos 
novamente nossa análise à consideração das elaborações marxianas podemos perceber que quem exerce essa função no capitalismo são os proletários, pois apenas eles produzem o capital e transformam a natureza nos meios de produção e de subsistência (MARX, 1996; TONET; LESSA, 2012).

Este fato nos remete à centralidade política do proletariado no sentido de que é a "classe operária, ou seja, a classe que produz a riqueza material, que é o polo dirigente do processo revolucionário". Tal raciocínio não quer dizer que os proletários sejam os únicos trabalhadores que efetivarão a revolução socialista, mas sim que, dentre todos os trabalhadores, os proletários são os sujeitos revolucionários por excelência, pela "sua posição no processo produtivo", isto é, são eles quem produzem "ao mesmo tempo a riqueza material e a mais-valia que vai resultar no capital" (TONET, 2008, p. 17).

É fundamental resgatarmos a discussão a respeito da centralidade ontológica do trabalho junto à centralidade política do proletariado para não incorrermos no equívoco de supervalorizar a práxis política na tarefa histórica dos trabalhadores de superarem qualitativamente o sistema do capital. Em razão disto, entendemos que a tarefa essencial, ou seja, social é a de fazer avançar, em todos os sentidos, o trabalho associado que será a matriz fundante do comunismo e o principal "indicador" de uma ofensiva socialista. Sem esta radical transformação "nas relações de produção, na forma de produzir a riqueza material, será inteiramente impossível a instauração de uma forma socialista de sociedade" (TONET, 2008, p. 18). Aí reside a necessidade de compreensão de que:

A análise da forma particular do trabalho na sociedade capitalista permite, por sua vez, concluir pela centralidade política do proletariado. Centralidade política no preciso sentido de que cabe a este, como protagonista fundamental, por sua posição no processo de produção, a tarefa de destruir o poder político da burguesia e de resgatar as forças sociais que foram apropriadas privadamente com o advento da propriedade privada, adquirindo uma forma particular no Estado moderno. A classe operária é a única classe autenticamente revolucionária, isto é, aquela cuja demanda essencial - a eliminação de toda forma de exploração do homem pelo homem - só pode ser alcançada pela supressão total do capital. Desde as Glosas críticas Marx já assinalava que a revolução proletária implica dois momentos: político e social. Político, no sentido de que tem como tarefa destruir o Estado burguês, braço que garante, por meio do poder político, a reprodução do capital. Em A guerra civil na França ele explicita, como vimos acima, com toda clareza a necessidade da destruição do Estado. Social, no sentido de que ela implica uma transformação radical no modo de produzir e distribuir a riqueza material. Como, porém, ficará claro em A guerra civil na França, o momento político é apenas uma mediação para a obtenção de um objetivo não político, isto é, a libertação econômica. (TONET, 2014, p. 04, grifos nossos).

Dessa forma, fica claro que resgatar o sentido da centralidade ontológica do trabalho na transição do capitalismo rumo ao socialismo não implica uma desqualificação ou desvalorização da práxis política. Entretanto, é preciso insistir que a política não é o "carro chefe" do processo revolucionário. A política é necessária para a tarefa de destruição do Estado burguês e de constituição da ditadura do proletariado, porém é essencial que se faça avançar a superação do trabalho assalariado/abstrato pelo trabalho associado em que há o controle livre, coletivo, consciente e universal do processo de trabalho (TONET, 2014).

Ao argumentarmos sobre a práxis política se conformando numa práxis ontológica ao ser social e não apenas circunscrita ao âmbito das sociedades de classes, não estamos caindo numa perspectiva reformista/idealista. A compreensão da centralidade ontológica do trabalho e suas articulações com os demais complexos sociais a partir de Marx e Lukács são reflexões 
de suma relevância para não colocarmos nos ombros da política o "momento predominante" no processo de transição do capitalismo rumo ao comunismo. A totalidade social se altera se a forma típica de organizar o trabalho e as relações sociais de produção forem alteradas. Claro que isto em nada despreza ou diminui a importância da atuação dos outros complexos sociais, apenas não lhes coloca uma tarefa impossível de realizar em razão da função social que desempenham. A práxis política, no processo revolucionário socialista, sendo uma forma específica de ideologia (como demonstramos no item anterior), pode contribuir no sentido de "induzir outra pessoa (ou grupo de pessoas) a realizar, por sua parte, pores teleológicos" (LUKÁCS, 2013, p. 83). Entretanto, os "pores teleológicos", neste caso em questão, devem, fundamentalmente, contribuir para o avanço do trabalho associado e a destruição total do Estado e do capital.

Importante notar que o trabalho associado - categoria fundante da sociabilidade comunista - não implica um cancelamento da política. No comunismo a política estará "desprivatizada" de seu conteúdo qualitativamente negativo e inerente às sociedades dominadas pelo capital e pela propriedade privada. Pensemos num exemplo palpável: a educação certamente continuará a existir numa sociedade comunista, todavia o formato de escola e de universidade extremamente burocratizantes e enfadonhos que vigoram no capitalismo desaparecerão. Nesse aspecto, quando os trabalhadores "livremente associados" se reunirem para decidir o que ensinar, de qual maneira, com quais atividades, em quais momentos e com quais finalidades; estaremos presenciando uma práxis política em sentido amplo, ou seja, sem as alienações que brotam do capital. Podemos pensar ainda no caso desses trabalhadores organizando o processo produtivo, o que produzir, de qual maneira, em que período do ano, etc.; também neste caso há uma práxis política só que, neste caso (no contexto do comunismo) se trata de uma política que não mais fora privatizada para atender aos interesses das classes dominantes.

Lukács, na sua Ontologia, em especial no capítulo dedicado à Marx, apresenta elementos importantíssimos para a reflexão a respeito da prioridade ontológica do trabalho associado como condição sine qua non para a edificação de uma forma de sociabilidade marcada pela emancipação humana. Explica o filósofo húngaro que cabe à produção a prioridade ontológica, ou seja, ela exerce, nesse contexto, o papel de momento predominante (LUKÁCS, 2012). Isto significa que o processo de produção e o de reprodução das condições materiais da existência social colocam o campo de possibilidades para a orientação e os rumos dos demais complexos sociais que irão consubstanciar uma determinada forma de sociedade.

As relações sociais de produção capitalista (por serem estruturalmente desiguais a partir do trabalho assalariado como seu fundamento) impossibilitam a existência de uma efetiva sociedade justa e emancipada humanamente. Aqui reside a importância do trabalho associado exercendo o papel de momento predominante no processo de transição socialista. Se a ideologia se consubstancia em uma função social de inferir praticamente perante um determinado conflito social, a ideologia revolucionária deve contribuir para que tanto teórica quanto praticamente o trabalho associado se coloquem como prioridade ontológica, ou seja, como momento predominante na luta contra o capital. 
Assim como no exemplo da casa de Aristóteles e retomado por Lukács (1981) como apresentamos na primeira parte do texto, de uma pedra ou madeira não deriva mecanicamente uma casa, tampouco uma forma superior de sociabilidade para além da exploração do homem pelo homem se constituirá de modo espontâneo. A práxis ideológica política é fundamental para os seres humanos optarem efetivamente pela superação completa do capital e, ao mesmo tempo, o trabalho associado deve exercer a sua função de fundamento ontológico indispensável para a construção da nova sociedade.

\section{CONSIDERAÇÕES FINAIS}

A relação entre trabalho, ideologia, práxis política e a totalidade social é por demais ampla e complexa. Escapa ao esboço de um artigo ou mesmo de um contato recente com a ontologia marxiana. Entretanto, acreditamos que os aprofundamentos dos estudos das obras de Marx, Lukács e Mészáros, nos próximos anos, possibilitarão uma apreensão mais clara a respeito destas determinações recíprocas.

Com efeito, entendemos que é fundamental resgatar 1) a centralidade ontológica do trabalho, 2) a centralidade política do proletariado e 3) a centralidade ontológica do trabalho no processo de transição do capitalismo rumo ao socialismo. Estas formulações são de extrema relevância tanto para a apreensão do correto relacionamento dos complexos sociais para com o trabalho (a dependência ontológica, autonomia relativa e determinação recíproca) e, ainda, para o entendimento sobre o complexo da política em um ponto de vista ontológico, ou seja, um ponto de vista que leva em consideração a análise histórica de complexificação do ser social com base na atividade dos próprios homens entre si e não em potências transcendentais.

A práxis política, tendo por base as pistas deixadas pelo próprio Lukács em sua "Ontologia" e também as análises de alguns pesquisadores de sua obra, se conforma numa forma específica de ideologia. É uma práxis universal, no sentido de que sempre esteve e estará presente no "mundo dos homens" e possibilita os indivíduos tomarem consciência e enfrentarem os conflitos sociais. Isto, contudo, não quer dizer que a política seja a "pedra de toque" do processo revolucionário. Certamente ela é uma práxis necessária na destruição do poder político burguês e no sentido de contribuir com a constituição da ditadura do proletariado. Porém, a matriz fundante do socialismo e que deve se fazer presente em todos os momentos é o trabalho associado, pois esta forma de trabalho irá determinar ontologicamente um campo de possibilidades objetivas reais que possibilitarão a política perder seu caráter negativo inerente à totalidade consubstanciada pelo sistema do capital. A influência que o trabalho associado exercerá nos complexos e na totalidade social permitirá desaparecer as desigualdades sociais e a exploração do homem pelo homem, já que implica uma transformação radical, qualitativa, uma revolução social que supera o capital no seu "nascedouro".

REFERÊNCIAS

CARLI, R. A política em Gyorgy Lukács. São Paulo: Cortez, 2013. 
CHASIN, J. O integralismo de Plínio Salgado - forma de regressividade no capitalismo hiper-tardio. São Paulo: Ed. Ciências Humanas, 1978.

HOLANDA, M. N. A. B. Lukács: Ontologia e Alienação. São Paulo: Instituto Lukács, 2014.

LESSA, S. Mundo dos homens: Trabalho e Ser Social. 3. ed. São Paulo: Instituto Lukács, 2012.

LUKÁCS, G. As Bases Ontológicas do Pensamento e da Atividade do Homem. Temas de Ciências Humanas n. 4. Tr. C.N. Coutinho, São Paulo: Livraria Editora Ciências Humanas, 1978.

LUKÁCS, G. Il Lavoro. In: LUKÁCS, G. Per una Ontologia dell'essere sociale. Roma: Riuniti, 1981, p. 11-131. (Tradução Mimeo.de Ivo Tonet, 145p.)

LUKÁCS, G. Para uma ontologia do ser social - I. São Paulo: Boitempo: 2012.

LUKÁCS, G. Para uma ontologia do ser social - II. São Paulo: Boitempo: 2013.

MARX, K. O Capital - Vol I. São Paulo: Nova Cultural, 1996.

MARX, K. Contribuição à crítica da Economia Política. São Paulo: Expressão Popular, 2008.

MÉSZÁROS, I. Para Além do Capital. São Paulo: Boitempo, 2002.

TONET, I. Educação, Cidadania e Emancipação Humana. Ijuí: Unijuí, 2005.

TONET, I. Socialismo: obstáculos a uma discussão. Clio, n. 26.1/2008. Disponível em: < http://ivotonet. xpg.uol.com.br/ >. Último acesso: set. 2015.

TONET, I.; NASCIMENTO, A. Descaminhos da esquerda: da centralidade do trabalho à centralidade da política. São Paulo: Alfa-Omega, 2009.

TONET, I.; LESSA, S. Proletariado e sujeito revolucionário. São Paulo: Instituto Lukács, 2012.

TONET, I. Trabalho Associado e extinção do Estado. Rebela, v. 3, n. 2, 2014.

VAISMAN, E. A determinação marxiana da ideologia. Tese (Doutorado em Educação) Universidade Federal de minas Gerais, Faculdade de Educação, 251p. 1996.

VAIMAN, E.; FORTES, R. V. A Politicidade no pensamento tardio de Gyorgy Lukács. Revista Estudos Políticos, v. 05, n. 01, pp. 118-132, 2014.

Artigo recebido em: 11/01/2017

Aprovado em: 14/08/2017

\section{CONTATO PARA CORRESPONDÊNCIA:}

Rafael Rossi.E-mail: rafaelrossi6789@hotmail.com 